\title{
PENGARUH KELENGKAPAN PERANGKAT PEMBELAJARAN TERHADAP HASIL BELAJAR FISIKA SISWA SMP KARTIKATAMA METRO KELAS VIII
}

\author{
Erni Mariana \\ Sains dan Teknologi, Universitas Nahdlatul Ulama Lampung, ernimariana@unulampung.ac.id
}

\begin{tabular}{l} 
INFO ARTIKEL \\
\hline Riwayat Artikel: \\
Diterima: 07-04-2018 \\
Disetujui: 20-04-2018 \\
\hline
\end{tabular}

Kata Kunci:

Kelengkapan Perangkat Pembelajaran

Hasil Belajar

\section{A. LATAR BELAKANG}

Hakikat pendidikan berfokus pada bagaimana siswa belajar. Pengertian belajar merupakan suatu proses perubahan. Yaitu perubahan tingkah laku sebagai hasil interaksi dengan lingkungannya dalam memenuhi kebutuhan hidupnya. Perubahan tersebut akan nyata pada seluruh aspek tingkah laku. Ciri khas dari belajar adalah perubahan. Belajar menghasilkan perubahan prilaku pada peserta didik. Perubahan tersebut terjadi sebagai hasil latihan, pengalaman dan pengembangan yang hasilnya tidak dapat diamati secara langsung. Belajar adalah aktivitas mental/psikis yang berlangsung dalam interaksi aktif dengan lingkungan yang menghasilkan perubahan-perubahan dalam pengetahuan, keterampilan, dan sikap [4]. Belajar dapat dipahami sebagai tahapan perubahan seluruh tingkah laku individu yang relatif menetap sebagai hasil pengalaman dan interaksi dengan lingkungan yang melibatkan proses kognitif [3].

Bagi dunia pendidikan, perangkat pembelajaran merupakan hal utama yang harus dimiliki dan diterapkan oleh guru mata pelajaran, karena dalam perangkat pembelajaran semua rancangan kegiatan proses pembelajaran itu akan dilaksanakan dalam proses belajar mengajar. Mulai dari perencanaan pembelajaran, pengembangan strategi, bahkan aplikasinya dari apa yang guru rencanakan agar sesuai dengan tujuan yang ingin dicapai semua itu ada dalam perangkat pembelajaran. 
Maka dari itu perangkat pembelajaran merupakan hal yang sangat berperan penting dalam kegiatan belajar mengajar dan pencapaian tujuan pembelajaran. Perencanaan pembelajaran adalah proses pengambilan keputusan hasil berfikir secara rasional tentang sasaran dan tujuan pembelajaran tertentu, yakni perubahan perilaku serta rangkaian kegiatan yang harus dilaksanakan sebagai upaya pencapaian tujuan tersebut dengan memanfaatkan segala potensi dan sumber belajar yang ada [7].

Hasil akhir dari proses pengambilan keputusan tersebut artinya ialah tersusunnya seperangkat dokumen yang berisikan tentang hal-hal yang menyangkut rancangan kegiatan pembelajaran yang akan guru laksanakan. Sehingga seperangkat dokumen tersebut dapat dijadikan sebagai acuan dan pedoman dalam melaksanakan proses pembelajaran.

Pendekatan sistem merupakan suatu perangkat alat atau teknik, alat-alat itu berbentuk kemampuan (abilitas) dalam:

1. Merumuskan tujuan-tujuan secara operasional.

2. Mengembangkan deskripsi tugas-tugas secara lengkap dan akurat.

3. Melaksanakan analisis tugas-tugas.

4. Alat-alat dan rancangan sistem pengajaran menuntut para guru agar dalam proses pembelajaran menyediakan kondisi belajar bagi siswa[2].

Desain sistem intruksional ialah pendekatan secara sistematis dalam perencanaan dan pengembangan sarana serta alat untuk mencapai tujuan intruksional [3]. Segala sesuatu yang mendukung terciptanya tujuan dalam proses pembelajaran itu merupakan perangkat pembelajaran meliputi silabus dan rencana pelaksanaan pembelajaran (RPP), modul, handout, dan lain sebagainya yang sekiranya mendukung proses pembelajaran.

Lembar kegiatan siswa (LKS) merupakan suatu media cetak karena LKS berupa lembaran printout yang berisi prosedur kegiatan bagi siswa. Lembar kegiatan siswa adalah panduan siswa yang digunakan untuk melakukan kegiatan penyelidikan atau pemecahan masalah [8]. Penggunaan LKS sangatlah berguna bagi guru karena dengan penggunaan LKS guru mendapat kesempatan untuk memancing peserta didik terlibat secara aktif dengan materi yang dibahas. Salah satu metode yang bisa diterapkan untuk mendapatkan hasil yang optimal dari pemanfaatan LKS adalah metode "SQ3R" atau survey, Question, Read, Recite, and Review (menyurvei, membuat pertanyaan, membaca, meringkas, dan mengulang) [5].

Data hasil pra survei tentang hasil belajar siswa kelas VIII SMP Kartikatama Metro dapat dilihat sebagai berikut :
TABEL 1

DATA NILAI HASIL BELAJAR SISWA KELAS VIII

SEMESTER GENAP SMP KARTIKATAMA METRO

\begin{tabular}{ccccc}
\hline No & KKM & Kategori & Jumlah Murid & Presentase \\
\hline 1. & $<70$ & Tidak Tuntas & 22 & $65 \%$ \\
2. & $\geq 70$ & Tuntas & 12 & $35 \%$ \\
\multicolumn{2}{c}{ JUMLAH } & 34 & $100 \%$ \\
\hline
\end{tabular}

Berdasarkan Tabel 1, dapat dilihat bahwa rata-rata hasil belajar fisika siswa SMP Kartikatama Metro belum mencapai hasil yang diinginkan, karena nilai kebanyakan siswa belum mencapai KKM yang ditetapkan yaitu 70. Hal ini dapat dilihat dari jumlah siswa yang belum tuntas sebanyak $65 \%$ dan siswa yang telah tuntas sebanyak $35 \%$. Jelas terlihat dari hasil nilai yang didapatkan bahwa kelas VIII SMP Kartikatama Metro mengalami kesulitan dalam hal memahami materi fisika. Maka dari itu perlu adanya suatu perbaikan dalam proses pembelajaran agar hasil belajar siswa sesuai dengan apa yang diharapkan.

Berdasarkan prasurvey, dalam proses pembelajaran guru menggunakan perangkat pembelajaran seperti silabus, RPP, dan buku pelajaran. Dalam hal ini yang digunakan guru memang perangkat yang umum digunakan dalam proses pembelajaran, hanya saja kegiatan pembelajaran yang dilaksanakan tidak sesuai dengan rencana pelaksanaan pembelajaran yang telah direncanakan sebelumnya, sehingga tidak tercapainya tujuan pembelajaran dan secara tidak langsung akan berdampak pada hasil belajar siswa. Kemudian dilihat dari kondisi siswa SMP Kartikatama Metro yang dominan siswanya mengalami kesulitan dalam pemahaman materi pelajaran, sedangkan guru hanya menggunakan buku paket dirasa kurang efektif untuk siswa dalam memahami materi. Bukan berati buku paket kurang baik digunakan, buku paket akan efektif digunakan jika disesuaikan dengan intensifnya guru tersebut menjelaskan dan terus mendampingi siswa dalam proses pembelajaran, sedangkan proses pembelajaran yang berlangsung tidak sesuai dengan RPP yang direncanakan secara tidak langsung hal tersebut akan berdampak pada kurang efektifnya penggunaan perangkat pembelajaran seperti buku paket.

Berdasarkan wawancara dengan guru IPA di SMP Kartikatama Metro, akan dilakukan tindakan dalam proses pembelajaran demi mengurangi masalah pemahaman materi pelajaran yang dialami siswa, solusi alternatif yang akan dilakukan adalah dengan melibatkan beberapa perangkat pembelajaran yang dapat membantu siswa dalam memahami materi pelajaran. Untuk itu penggunaan beberapa perangkat pembelajaran harus disesuaikan baik fungsinya dan keterlaksanaannya dalam proses pembelajaran. Seperti silabus digunakan sebagai acuan pembuatan RPP, kemudian kegiatan pembelajaran disesuaikan dengan rencana pembelajaran yang telah dirancang sebelumnya, bila dirasa penggunaan buku paket kurang efektif untuk siswa maupun guru dalam menyampaikan materi, bisa 
digunakan alternatif penggunaan perangkat tersebut, seperti halnya handout dan LKS.

Berdasarkan masalah di atas, maka penggunaan perangkat pembelajaran yang lengkap dalam proses pembelajaran bisa sangat membantu bagi siswa maupun guru. Karena perangkat pembelajaran dalam proses pembelajaran jika digunakan secara tepat dan efektif maka bukan menjadi hal yang tidak mungkin tingkat pemahaman siswa dan hasil belajar siswa akan mengalami perubahan menjadi lebih baik, sehingga hal tersebut dapat mengurangi kesulitan belajar siswa tersebut terhadap mata pelajaran fisika. Berdasarkan uraian di atas maka penulis mengambil judul : "Pengaruh Kelengkapan Perangkat Pembelajaran Fisika terhadap Hasil Belajar Fisika Siswa SMP Kartikatama Metro Kelas VIII".

Berdasarkan latar belakang di atas maka rumusan masalah dalam penelitian ini adalah, apakah terdapat pengaruh penggunaan kelengkapan perangkat pembelajaran fisika terhadap hasil belajar fisika siswa kelas VIII SMP Kartikatama Metro?

Adapun tujuan penelitian ini adalah, untuk mengetahui adanya pengaruh kelengkapan perangkat pembelajaran fisika yang digunakan dalam proses pembelajaran terhadap hasil belajar fisika siswa SMP Kartikatama Metro.

\section{B. METODE PENELITIAN}

Penelitian ini merupakan penelitian Eksperimen, dengan Randomized Control-Group Pre test-Post test Design, desain ini menggunakan dua kelompok yang akan diteliti [1]. (Kelompok pertama mendapatkan perlakuan (treatment) atau disebut sebagai kelas eksperimen yaitu kelas yang pembelajarannya menggunakan perangkat pembelajaran yang lengkap, sedangkan kelompok yang kedua menggunakan kelompok pengendali (control) atau disebut sebagai kelas kontrol yaitu kelas yang pembelajarannya menggunakan perangkat pembelajaran seperti biasa yang sering digunakan oleh guru. Teknik ini menggunakan tes berbentuk pretes dan postes, dengan desain Randomized Control-Group Pretest-Posttest Design. Penelitian dilaksanakan di SMP Kartikatama Metro, pada kelas VIII khususnya kelas VIII $_{\mathrm{B}}$ dan $\mathrm{VIII}_{\mathrm{D}}$ sebagai kelas eksperimen dan kelas kontrol yang terpilih dengan cara random.

Sebelum penelitian dilaksanakan maka untuk memperoleh hasil pengukuran data yang valid (sahih) dan reliabel, dilakukan validitas instrument melalui penilaian ahli yang terdiri dari 3 validator dan untuk reabilitas tes yang akan digunakan. Teknik analisis data yang digunakan dalam penelitian ini meliputi uji normalitas sampel, uji homogenitas dan uji perbedaan dua rata-rata.

\section{HASIL DAN PEMBAHASAN}

Berdasarkan hasil penelitian yang telah dilakukan, perolehan data hasil belajar siswa yang diperoleh setelah melakukan pretest (tes awal) dan posttest (tes akhir), dan perhitungan data nilai rata-rata hasil belajar siswa serta jumlah siswa dapat dilihat pada lampiran. Adapun ringkasan deskripsi data disajikan dalam tabel berikut :

TABEL 2

NILAI RATA-RATA HASIL BELAJAR SISWA, JUMLAH SISWA, DAN RATA-RATA GAIN TERNORMALISASI PADA KELAS EKSPERIMEN

Kelas Eksperimen

\begin{tabular}{cccc}
$\begin{array}{c}\text { Jumlah } \\
\text { siswa }\end{array}$ & $\begin{array}{c}\text { Kata-rata hasil belajar siswa } \\
\text { Pretest }\end{array}$ & Posttest & Gain \\
\hline 33 & 18,94 & 83,87 & 0,78 \\
\hline
\end{tabular}

TABEL 3

NILAI RATA-RATA HASIL BELAJAR SISWA, JUMLAH SISWA, DAN RATA-RATA GAIN TERNORMALISASI PADA KELAS KONTROL

\begin{tabular}{|c|c|c|c|}
\hline \multicolumn{4}{|c|}{ Kelas Kontrol } \\
\hline \multirow{2}{*}{$\begin{array}{c}\text { Jumlah } \\
\text { siswa }\end{array}$} & \multicolumn{2}{|c|}{ Rata-rata hasil belajar siswa } & \multirow{2}{*}{ Gain } \\
\cline { 2 - 3 } & Pretest & Posttest & \\
\hline 31 & 18,23 & 73,71 & 0,66 \\
\hline
\end{tabular}

Berdasarkan Tabel 2 dan Tabel 3 di atas dapat diuraikan mengenai peningkatan hasil belajar siswa sebagai berikut :

1) Peningkatan hasil belajar fisika siswa pada kelas sampel secara keseluruhan dapat dilihat dari hasil posttest siswa pada kelas eksperimen hasil posttestnya 83,87 sedangkan pada kelas kontrol hasil posttestnya 73,71. Hal ini menunjukan bahwa hasil belajar siswa mengalami peningkatan dan dapat dikatakan dalam kategori baik.

2) Perbandingan gain antara kelas eksperimen dan kelas kontrol adalah untuk kelas eksperimen 0,78 dan untuk kelas kontrol adalah 0,66. Hal ini menunjukkan bahwa peningkatan hasil belajar kelas eksperimen lebih baik dari pada kelas kontrol. jika diinterprestasikan dalam indeks gain maka gain pada kelas eksperimen tinggi dan gain pada kelas kontrol sedang.

Perbandingan antara pretest, posttest, dan gain ternormalisasi dapat dilihat pada gambar berikut ini.

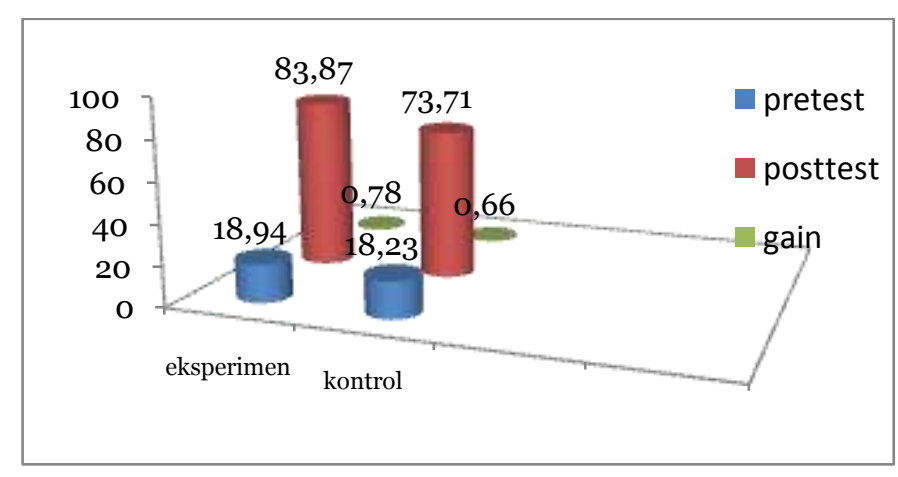

Gambar 1. Grafik Perbandingan Pretest, Posttest, Dan Gain Ternormalisasi 
Data observasi ini menjelaskan tentang penggunaan perangkat pembelajaran saat proses pembelajaran berlangsung.

Data yang dianalisis ialah data $N$-gain yang diperoleh dari hasil pretest dan posttest. Analisis data meliputi uji normalitas (uji kecocokan chi kuadrat) dan uji homogenitas (uji F). Setelah didapat hasil uji normalitas dan homogenitas baru selanjutnya dilakukan uji perbedaa dua rata-rata menggunakan uji-t untuk menguji hipotesis. Uji normalitas bertujuan untuk mengetahui apakah sampel yang dijadikan penelitian berasal dari populasi berdistribusi normal atau tidak. Dan uji homogenitas bertujuan untuk melihat apakah antara kedua sampel homogen atau tidak.

\section{Uji Normalitas Data}

Data hasil uji normalitas sampel disajikan dalam tabel berikut:

\section{TABEL 4}

REKAPITULASI INTERPRETASI UJI NORMALITAS

\begin{tabular}{|c|c|c|c|c|}
\hline \multirow{2}{*}{ Kelas } & \multirow{2}{*}{$\mathrm{x}^{2}$ hitung } & \multicolumn{2}{|c|}{$\mathrm{x}^{2} \mathrm{daf}$} & \multirow{2}{*}{ Kesimpulan } \\
\hline & & $5 \%$ & $1 \%$ & \\
\hline Eksperimen & 2,4569 & 7,81 & 11,3 & Terima $\mathrm{H}_{\mathrm{o}}$ \\
\hline Kontrol & 2,2704 & 7,81 & 11,3 & Terima $\mathrm{H}_{\mathrm{o}}$ \\
\hline
\end{tabular}

Berdasarkan tabel 4 dapat dijelaskan beberapa hal yaitu diketahui bahwa $X^{2} h i t<X^{2}$ daftar baik pada kelas eksperimen maupun kelas kontrol. Hal ini menyatakan bahwa keterampilan proses sains siswa sebagai hipotesis berdistribusi normal atau $\mathrm{H}_{\mathrm{o}}$ diterima.

\section{Uji Kesamaan Dua Varians Homogenitas)}

(Uji

Data hasil uji homogenitas sampel disajikan dalam tabel berikut:

\section{TABEL 5}

NILAI F ANTARA VARIANS DISTRIBUSI HASIL BELAJAR

\begin{tabular}{ccccc}
\hline Kelas & Varian $\left(\mathrm{S}^{2}\right)$ & $\mathrm{F}=\frac{\mathrm{s}^{2} \text { besar }}{\mathrm{s}^{2} \text { kecil }}$ & \multicolumn{2}{c}{$\mathrm{F}_{\text {daf }}$} \\
\hline Eksperimen & 44,9337 & 1,07 & $10 \%$ & $2 \%$ \\
Kontrol & 41,9892 & 1,07 & 1,84 & 2,38 \\
\hline
\end{tabular}

Berdasarkan Tabel 5 dapat dijelaskan bahwa $F_{h i t}<$ $F_{\text {daf }}$ sehingga $\mathrm{H}_{\mathrm{o}}$ diterima, dengan kata lain kedua populasi mempunyai varian yang homogen.

TABEL 6

UJI PERBEDAA DUA RATA-RATA HASIL BELAJAR SISWA

\begin{tabular}{|c|c|c|c|}
\hline \\
\hline$t_{\text {hit }}$ & $t_{d a f}(\alpha=0,05)$ & $t_{d a f}(\alpha=0,01)$ & kesimpulan \\
\hline 3,87 & 1,67 & 2,00 & $\mathrm{H}_{1}$ diterima \\
\hline
\end{tabular}

Berdasarkan tabel 6, dapat dijelaskan beberapa hal yaitu diketahui $t_{\text {hit }}>t_{\text {daf }}$ sehingga $\mathrm{H}_{1}$ diterima. Hal ini mengindikasikan penolakan pada $\mathrm{H}_{\mathrm{o}}$, sehingga dapat disimpulkan bahwa rata-rata hasil belajar siswa kelas eksperimen lebih tinggi daripada hasil belajar siswa kelas kontrol.
Berdasarkan analisis dari hasil uji hipotesis diketahui bahwa adanya suatu perbedaan dari hasil belajar siswa. Perbedaan tersebut diketahui pada uji perbedaan dua rata-rata, pada uji perbedaan dua ratarata ini diketahui bahwa hasil belajar siswa yang dalam proses pembelajrannya menggunakan perangkat pembelajaran yang lengkap dan digunakan secara efektif dengan siswa yang dalam proses pembelajarannya menggunakan perangkat pembelajaran yang tidak lengkap diketahui hasil $t_{\text {hit }}>t_{d a f}$ dimana pada uji perbedaan dua rata-rata ini diketahui $t_{\text {hit }}=3,8737$ sedangkan $t_{d a f}=1,67$, sehingga dikatakan $\mathrm{H}_{0}$ ditolak dan $\mathrm{H}_{1}$ diterima. Dari hasil analisis dan uji tersebut dapat dikatakan juga bahwa terdapat perbedaan yang signifikan antara hasil belajar pada kelas eksperimen dan kelas kontrol. Dengan terlihatnya perbedaan hasil belajar antara kelas eksperimen dan kelas kontrol, dapat disimpulkan bahwa pembelajaran yang menggunakan perangkat pembelajaran lengkap berpengaruh terhadap peningkatan hasil belajar fisika siswa.

Berdasarkan hal tersebut kelengkapan perangkat pembelajaran yang digunakan dalam proses pembelajaran pada penelitian ini ternyata berdampak, hal ini dapat dilihat dari peningkatan hasil belajar siswa. Peningkatan hasil belajar siswa tersebut dapat dilihat pada hasil analisis dan uji perbedaan dua rata-rata di atas. Beberapa perangkat pembelajaran yang digunakan dalam penelitian ini meliputi silabus dan rencana pelaksanaan pembelajaran (RPP) yang digunakan sebagai pedoman saat proses pembelajaran, handout digunakan sebagai sumber materi pembelajaran yang disajikan secara ringkas dan jelas yang berasal dari beberapa sumber yang sesuai dengan materi yang diajarkan, sedangkan LKS digunakan sebagai panduan bagi siswa untuk melakukan percobaan dan penguasaan konsep siswa. Ditinjau dari fungsi dan kegunaannya masing-masing penggunaan beberapa perangkat pembelajaran dalam penelitian ini banyak membantu siswa maupun guru dalam berlangsungnya proses pembelajaran. Seperti halnya penggunaan handout dalam proses pembelajaran, penggunaan handout dalam proses pembelajaran membantu siswa sebagai contoh siswa menjadi lebih fokus terhadap materi pelajaran yang disampaikan. Hal ini dapat terlihat dari sebagian besar siswa yang memperhatikan dengan baik ketika guru menyampaikan materi pelajaran, karena siswa tidak perlu mencatat lagi sehingga perhatian siswa hanya pada penjelasan guru.

Penggunaan handout juga dapat memudahkan siswa dalam memahami materi, hal ini dikarenakan handout merupakan suatu media cetak yang dibuat secara ringkas dan dengan bahasa yang mudah dimengerti oleh siswa yang berisi ringkasan materi pelajaran yang bersumber dari beberapa sumber yang sesuai dengan materi yang di ajarkan. LKS digunakan sebagai pedoman bagi siswa dalam kegiatan percobaan. Penggunaan LKS dalam proses pembelajaran membantu 
siswa pada kelas eksperimen lebih memahami materi hanya mereka melakukan pengamatan secara berkelompok, dan menyimpulkan hasil pengamatannya. LKS yang digunakan dapat membuat siswa menjadi lebih aktif, hal ini ditunjukkan dari antusias siswa pada kegiatan pratikum yang dilaksanakan, sehingga pelajaran yang berlangsung terasa berbeda dan tidak membosankan.

Penggunaan LKS melatih siswa untuk melakukan percobaan atau praktikum secara sistematis, hal ini dapat dilihat ketika siswa melakukan percobaan mereka harus melakukan tahapan-tahapan atau prosedur kerja sesuai dengan yang tercantum dalam LKS yang dibuat. Penggunaan handout dan LKS pada penelitian ini tidak terlepas dari perencanaan pelaksanaan kegiatan pembelajaran, seluruh kegiatan baik penggunaan handout maupun LKS semua telah di rencanakan sedemikian rupa sehingga penggunaan handout maupun LKS dapat terlaksana sesuai dengan yang diharapkan. Hal ini dapat dilihat dari lembar observasi keterlaksanaan kegiatan pembelajaran, sehingga penggunaan handout maupun LKS dapat seefektif mungkin digunakan dan berdampak positif bagi perkembangan hasil belajar siswa. Maka dari itu sangat diperlukan kelengkapan perangkat pembelajaran yang digunakan dalam proses pembelajaran, ditinjau dari fungsinya yang memudahkan semua pihak dalam proses belajar baik itu guru maupun siswa.

\section{SIMPULAN DAN SARAN}

Berdasarkan analisis diatas dapat disimpulkan bahwa penggunaan kelengkapan pembelajaran, berpengaruh secara signifikan terhadap hasil belajar siswa kelas VIII SMP Kartikatama Metro.

Berdasarkan hasil penelitian ini maka peneliti dapat memberikan saran sebagai berikut:

1. Bagi siswa

Agar siswa mendukung penggunaan perangkat pembelajaran ini dengan lebih baik dan berpartisipasi dalam kegiatan pembelajaran yang berlangsung. Bersikap baik, dan respect terhadap apa yang diarahkan oleh guru. Sehingga suasana kelas menjadi kondusif.

2. Bagi Guru

Bagi guru untuk lebih memperhatikan kelengkapan pembelajaran dalam proses pembelajaran, karena didalamnya tertuang rancangan dan rencana pembelajaran yang akan dilakukan, kelengkapan perangkat pembelajaran bukan hanya formalitas semata tapi jika kelengkapan perangkat pembelajaran digunakan dalam proses pembelajaran secara efektif, akan mampu menimbulkan kemudahan dan dampak positif bagi guru maupun peningkatan hasil belajar siswa.

3. Bagi Peneliti Selanjutnya

Hasil penelitian ini bisa dijadikan referensi untuk mengembangkan penelitian selanjutnya, ditinjau dari pentingnya peranan perangkat pembelajaran diharapkan untuk lebih mengembangkan dan memperhatikan penggunaan perangkat pembelajaran dalam proses pembelajaran.

\section{DAFTAR RUJUKAN}

[1] Arikunto, S., Prosedur Penelitian, Rineka Cipta, Jakarta, 2010.

[2] Hamalik, O., Perencanaan Pengajaran Berdasarkan Pendekatan Sistem, Bumi Aksara, Jakarta, 2011.

[3] Harjanto, Perencanaan Pengajaran, Rineka Cipta, Jakarta, 2008.

[4] Muhibbin. Psikologi Pendidikan, PT Remaja Rosdakarya, Bandung, 2011.

[5] Prastowo, A., Panduan Kreatif Membuat Bahan Ajar Inovatif, Diva Press, Jogjakarta, 2011.

[6] Purwanto, Evaluasi Hasil Belajar, Pustaka Pelajar, Yogyakarta, 2010.

[7] Sanjaya, W., Perencanaan dan Desain Sistem Pembelajaran, Grafika, Bandung, 2008.

[8] Trianto, Mendesain Model Pembelajaran InovatiifProgresif, Prenada Media, Jakarta, 2009. 